\title{
GLUCAN STIMULATES THE ANTIBODY RESPONSE TO A T-DEPENDENT ANTIGEN IN CHICKENS
}

\section{BENDA, E. PETROVSKÝ, ${ }^{1}$ A. HAMPL ${ }^{1}$ and Jaromíra KALOVÁ ${ }^{2}$}

1. Institute of Animal Physiology and Genetics, Czechoslovak Academy of Sciences, 10400 Prague, Czechoslovakia

2. Department of Animal Physiology and Morphology, University of Agriculture, 613 Brno.

Received March 2, 1989

\section{Abstract}

B e n d a V., E. Petrovský, A. Ha m pl and J a r o míra Ka 1 o vá: Glucan Stimulates the Antibody Response to a T-Dependent Antigen in Chickens. Acta vet. Brno, 58, 1989: 345-351.

In hens of two commercial layer breeds (WL and RIR) the effect was studied of glucan administered simultaneously with suspensions of natural antigens - sheep red blood cells (SRBC) and Brucella abortus (BA). The stimulating effect of glucan in a dose of $10 \mathrm{mg} / \mathrm{kg}^{-1}$ was manifested in both lines by a remarkable increase of antibodies against SRBC. Nevertheless, the influence of glucan on the humoral immune response to the BA, a thymus-independent antigen, was rather non significant.

Glucan, immunostimulation, adjuvant, humoral immunity, domestic fowl

Similarly as in the other intensive breeds of farm animals, classic infectious diseases of poultry are actually suppressed by the complex of efficient precautions. Nevertheless, they have been stepwise replaced by subclinically occurring diseases, frequently induced even by non-pathogenic organisms, which may be manifested by the growth depression of the young poultry and by decreasing the population fitness in adult layers. ( $\mathrm{J}$ e $\mathrm{n} \mathrm{d} \mathrm{r} \mathrm{e} \mathrm{y} \mathrm{k} \mathrm{o} \mathrm{1987).} \mathrm{These} \mathrm{pathological}$ conditions are tightly related to the immune system, whose optimal function also determines the success of vaccination programmes. In spite of having the type of the immune response determined genetically, it is possible to improve the resistance of the poultry by a suitable selection ( $\mathrm{Cr}$ i t $\mathrm{t}$ e $\mathrm{n}$ d e $n$ 1983; V a n d e r Z i j p p 1983). A further possibility of affecting the immunity and thus also resistance of animals is in administering substances with immunomodulating effects, which exert their ever growing importance in the veterinary medicine ( $M$ u l c a p h y and $Q$ u in n 1986).

In our experiments, we tried to check the immunostimulating effect of glucan known in rodents ( $\mathrm{R} \mathrm{i} \mathrm{g} \mathrm{g} \mathrm{i} \mathrm{and} \mathrm{D} \mathrm{i} 1$ u z i 1961 ), in hens immunized simultenaously with natural antigens.

\section{Materials and Methods}

\section{Chickens}

Two commercial layer breeds were studied - White Leghorn (WL) and Rhode Island Red (RIR). The groups of hens $(n-10)$ were housed in cages and immunized in the age of 22 to 26 weeks.

\section{Glucan}

The particular form of glucan - 1,3 polysacharose - was prepared from the yeast Saccharomyces cerevisiae at the Institute of Microbiology, Czechoslovak Academy of Sciences, Prague, by a formerly described method ( $D$ i 1 u z i o et al. 1979). Before the administration, the substance was slowly dissolved in distilled water and applied in doses of 10 or $15 \mathrm{mg} . \mathrm{kg}^{-1}$. 
Immunisation

Sheep red bloods cells (SRBC) or the crude antizen prepared from the Bnucella abortus (BA) strain S99. Weybridge (Bioveta, Ivanovice, Czechoslovalia) were used for the immunization in the form of a $10 \%$ suspension in the physiologie saline. The hens were immunized intramuscularty with $1,5 \mathrm{ml}$ of the suspension containing the mixture of antigen with elucan. In controls, physiologic saline was administered instead of the glucan suspension. Blood samples for determining the antibodies by the arelutination in microtitration plates (SRBC) or test tubes (BA) (Koh-i-noor, Dalexin, Czochoslovakia) ( $\mathrm{P}$ e t r o v s k y $\&$ al. 1987) were usually taken in ono-weok intervals. The highest dilution of the blood serum exerting a significant aeglutination activity was considered as a sample titre and it was expressed as log2.

Statistical analysis

The means were separated with Student's test on $0,05(x)$ or $0,01(x x)$ level.

\section{Results}

Breed differences in the glucan activity

As shown in Fig. 1, there was a significant increase of the antibody-production In experimental groups of both breeds against the SRBC on the 14 th day p. im. In the WL breed the same result was observed already one week earlier where the titre was increased almost by three dilutions. The stimulating activity of glucan in a combination with the BA antigen was, however, significant in neither breed (Fig. 2).

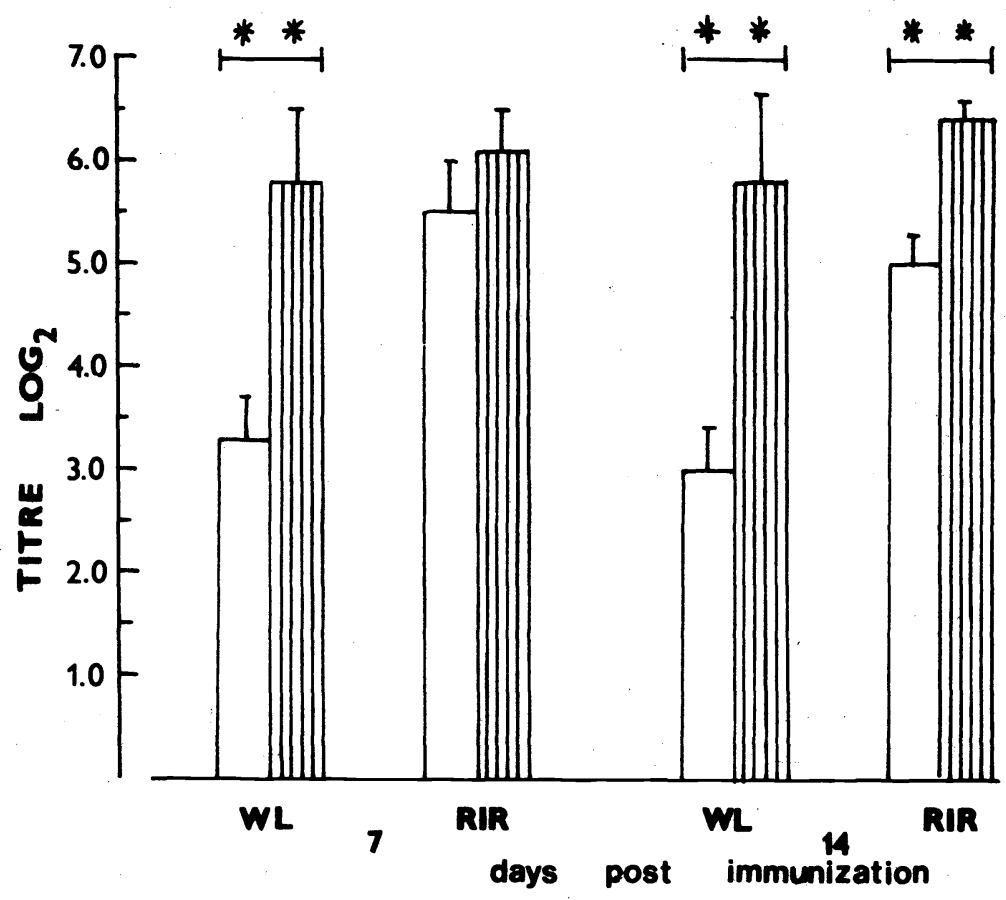

Fig. 1. Antibody response to SRBC in WL and RIR glucan treated (10 mg.kg-1) (striped bars) and control (wide bars) chickens (mean \pm S. D.) 


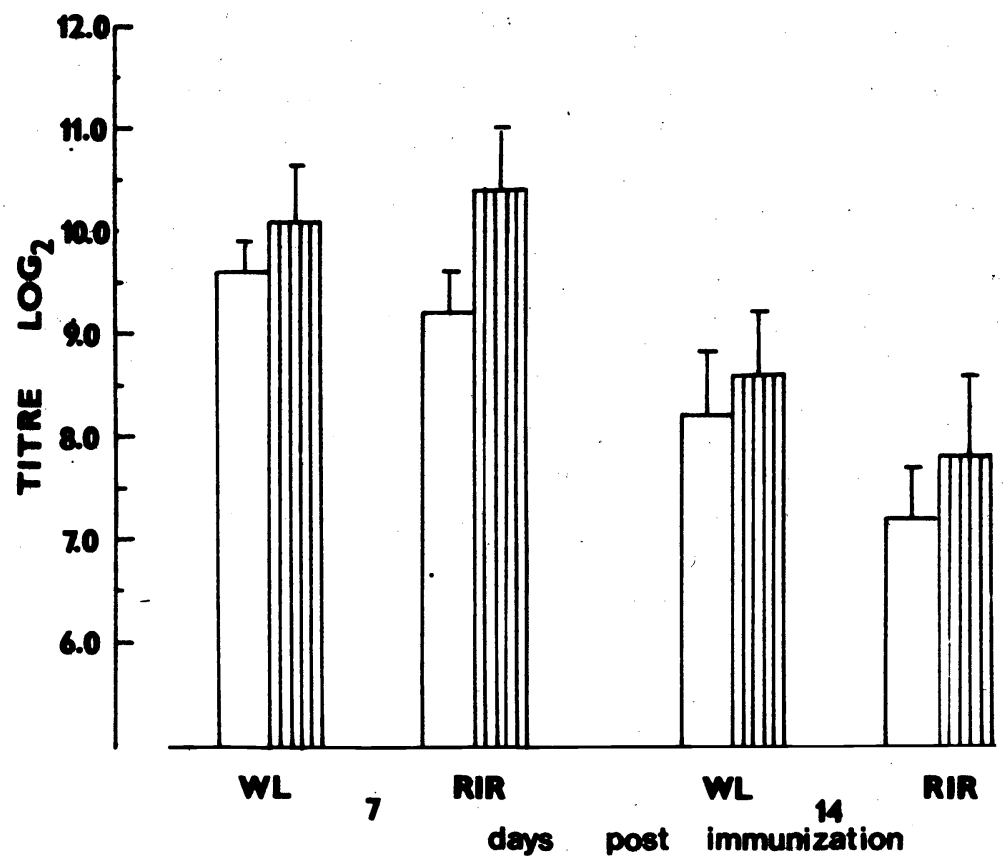

Fig. 2. Antibody response to BA in WL and RIR glucan treated (10 mg.g.1) (striped bars) and control (wide bars) chickens (mean \pm S. D.)

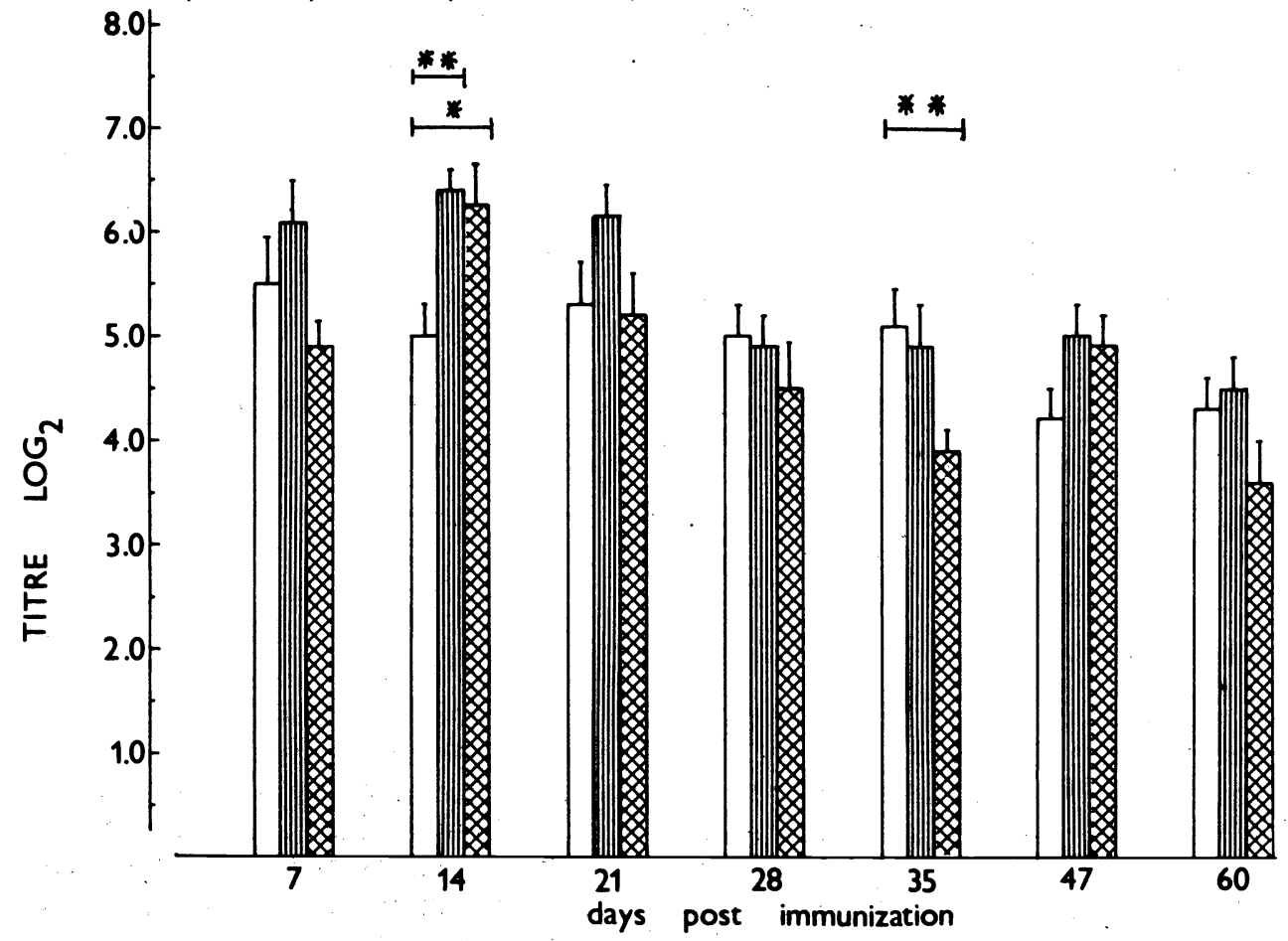

Fig. 3 Antibody response to SRBC in RIR chickens treated with $10 \mathrm{mg} \cdot \mathrm{g}^{-1}$ (striped bars), 15 mg. - $^{-1}$ (cross striped bars) of glucan or controls (wide bars) (mean \pm S. D.) 
The influence of different glucan doses on antibody response

In RIR hens, when repeating the experiment, the stimulating effect was manifested, again, in the case of the basic $\left(10 \mathrm{mg} . \mathrm{kg}^{-1}\right)$ as well as enhanced (15 mg. $\mathrm{kg}$ ) doses of glucan, 14 days after the immunization with the SRBC. Nevertheless, the enhanced dose resulted in moderate to significant (35th day) decrease of the antibody titre followed in all the remaining intervals (Fig. 3). A prolongation of the time of sampling after the immunisation with the BA up to the 60th day supported results of the preceding experiment but demonstrated a significantly positive effect of glucan one month after the immunization (Fig. 4). The blood sera of these hens were stimultaneously examined for the presence of antibodies against the SRBC with finding a significant increase of the titre in the case of three samplig intervals (14th, 21st and 60th days) in the experimental group as compared to controls where the antigen BA was administered without glucan (Fig. 5). The glucan administration does not affect negatively the health condition of the hens.

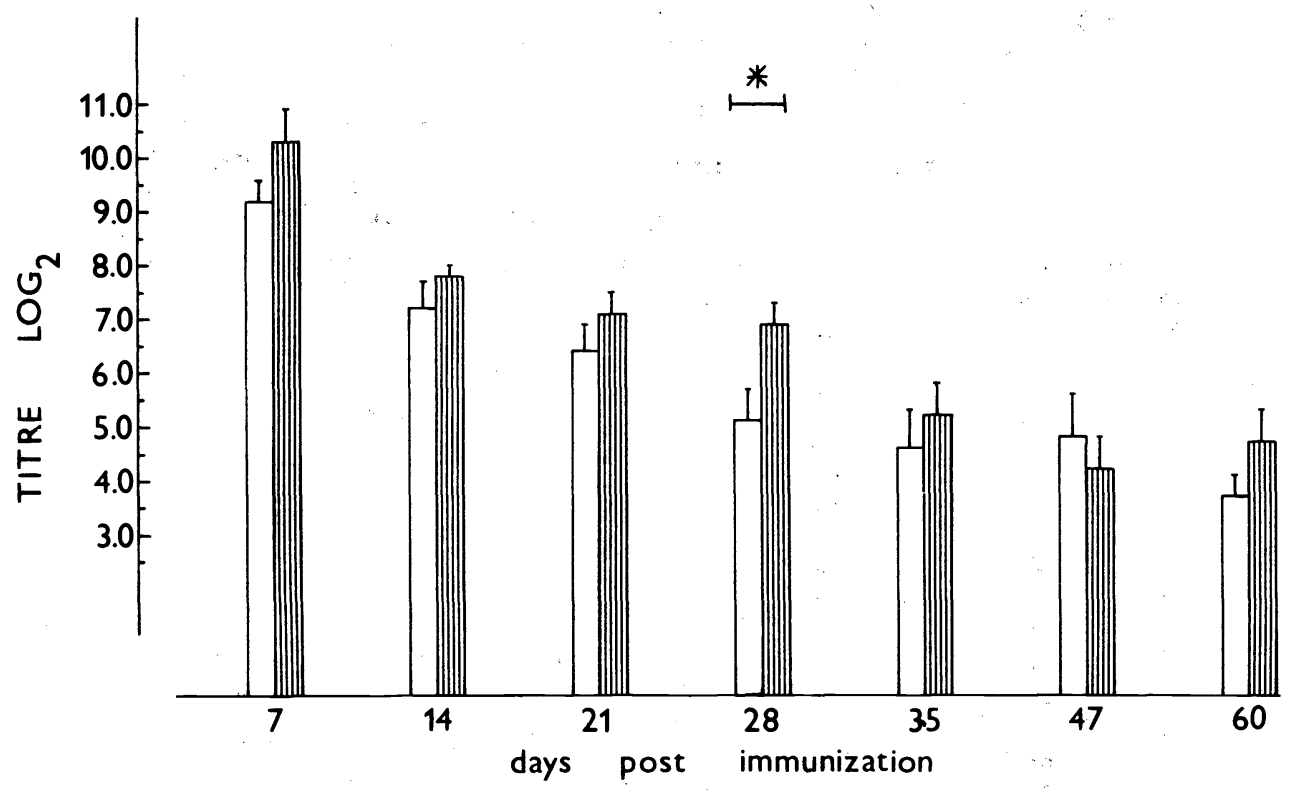

Fig. 4 Antibody response to BA in RIR glucan treated (10 mg. $\left.\mathrm{g}^{-1}\right)$ (striped bars) and control (wide bars) chickens (mean \pm S. D.)

\section{Discussion}

A wide spectrum of immunomodulation, adjuvant as well as therapeutic effects of glucan was reviewed by D i l u z i o and W i l l i a m s (1983). A growing body of data is positive, concerning immunologic mechanisms serving for the manifestation of the favourable glucan effect, where besides the activation of macrophages and stimulation of producing the complement by an alternative pathway, it potentiates particularly the thymus-dependent immunity ( $\mathrm{M} \mathrm{u} \mathrm{l} \mathrm{c} \mathrm{a} \mathrm{h} \mathrm{y}$ and $\mathrm{Qu}$ i n $\mathrm{n} \mathrm{1986)}$ ). Our results also indicate that the adjuvant effect of glucan was manifested just with the SRBC, whose antigen presentation is associated 


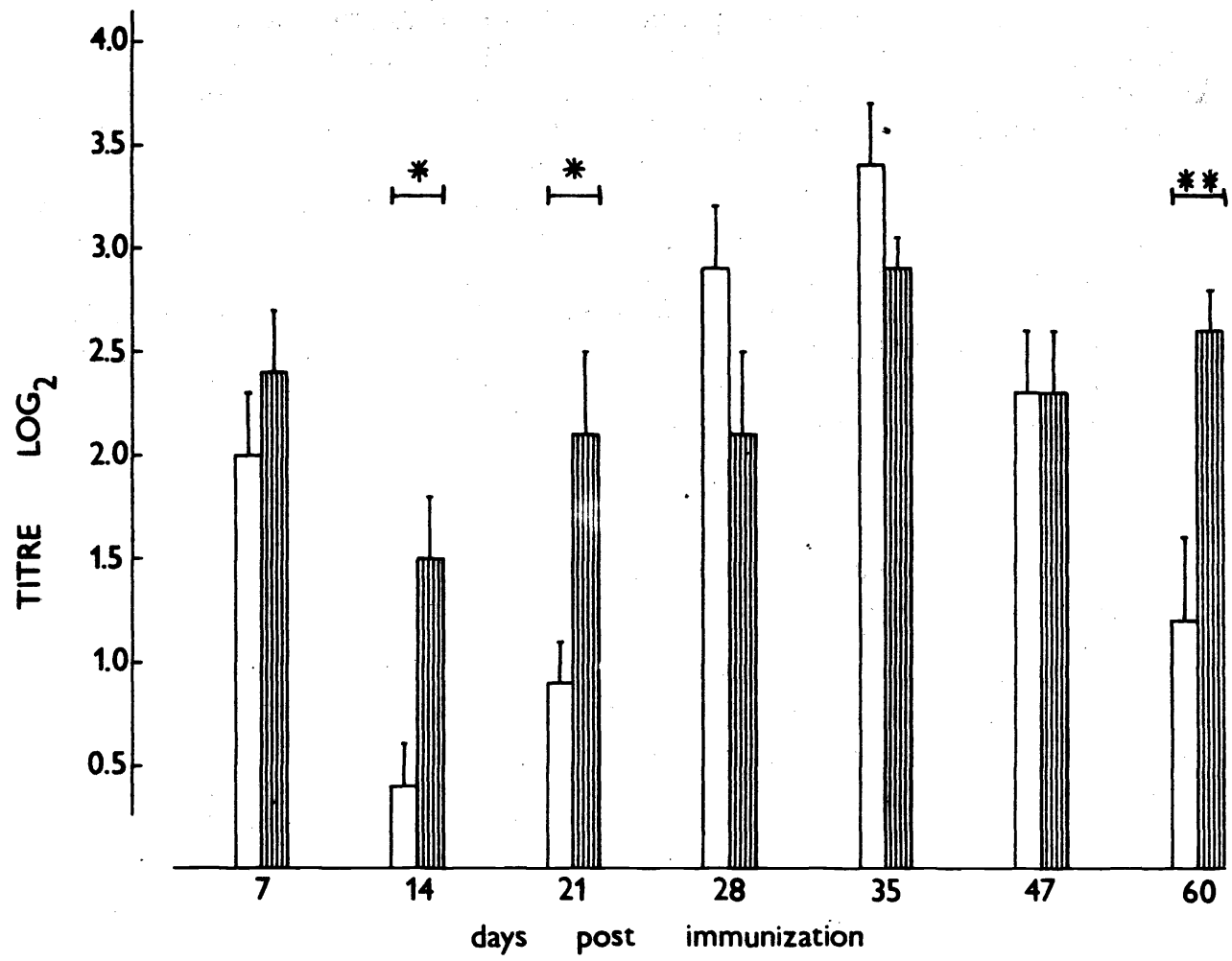

Fig. 5. Activity of SRBC antibodies in RIR chickens immunized with BA and treated with glucan (10 mg.g.1) (striped bars) or controls (wide bars) (mean \pm S. D.)

with a cooperation of $\mathrm{T}$ and $\mathrm{B}$ lymphocytes. This finding was obtained in both breeds but a more rapid development of the antibody production in WL hens suggests possible genetic influence even in the pharmacologic immunomodulation. The fact that the same dose of glucan did not affect essentially the humoral response to the T-independent antigen (BA) is also known in other adjuvants e. g. Freund's one. It is still impossible to draw an unambiguous conclusion about such selective character of glucan. Because of a lack of data concerning its precise dosage in the poultry, we use the rodent administration scheme (B ow e r s et al. 1986). The possibility of a remarkable manifestation of the dose during the immunomodulation is also shown by experiences from another agent, which is also of a microbial origin, muramyl dipeptide, whose stimulation effect can be turned into immunosuppression by increasing the dose (W a r r e n et al. 1986). A similar effect was also observed in our chickens teated with $50 \%$ higher dose of glucan (15 mg.kg.1). Besides the favourable effect of basic doses of glucan on the production of antibodies against the SRBC, which may be considered as an adjuvant effect, we also recorded a remarkable immunostimulation effect, where after its administration with the BA there was also a significant increase of antibody titres to SRBC without their use for the immunization. A similar result was found not only in an immunomodulant prepared from the germ Bordetella pertussis (W a r r e $\mathrm{n}$ et. al. 1986), 
but also in a classic chemotherapeutic agent with cancerostatic effects - cisdiamine dichloroplatinum ( $\hat{R} i \mathrm{~h}$ o vá et al. 1984). In these substances the duthors consider their specific effect on selected populations of immunocompetent cells, whose enhanced activity can also be manifested, besides others, by a general stimulation of the production of immunoglobulins.

The study of immunostimulation drugs in the veterinary medicine is of a great current interest in a connection with an increasing rate of occurrence of immunity disturbance in farm animals as well as with the development of modern vaccines with reduced antigenicity. In the poultry, where similar aubstances have not still found their extensive use, except for levamisole (C o n f e r and Al d i n g e r 1981), a deeper attention should be paid to the problems of the pharmacological immunomodulation.

Gluken stimuluje protilstkovou odpoved kura

k T-dependentmimu antigenu

U slepic dvou komerčních nosných plemen (WL a RIR) byl sledován účinek glukanu podaného simultánně se suspenzemi přirozených antigenú - ovč́ch krvinek (SRBC) a Brucella abortus (BA). Stimulační účinek glukanu v dávce $10 \mathrm{mg} \cdot \mathrm{g}^{-1}$ se projevil u obou linií výrazným zvýšením hladiny protilátek $\mathrm{k}$ SRBC. Nicméně, vliv glukanu na humorální imunitní odpověd k BA, antigenu na thymu nezávislém, vesměs prủkazný nebyl.

\section{Глокан стимулирует отеет антител курищн х Т-депендентому антигену}

У куриц-несушек двух коммерческих пород (WL и RIR) проводились исследования действия глюкана, подаваемог синхронно с суспензиями естественных антигенов - кровяных телец овец (SRBC) и Brucella

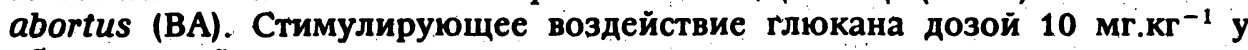
обеих линий проявилось существенным повышением уровня антител к SRBC. Tем не менее, влияние глюкана на гуморальный иммунитетный ответ к BA, антигена, не зависящем от тимуса, в общем не было убедительным.

\section{References}

BOWERS, G. J. - PATCHEN, M. L. - MACVITTIE T. J. - HIRCH, E. F. - FINK, M. P.: A comparative evaluation of particulate and soluble glucan in an endotoxin model. Int. J. Immunopharmacol., 8, $1986: 313-321$.

CONFER, A. W. - ALDINGER, W. K. The in vivo effect of Levamisole on PHA stimulation in normal and Marek's virus inoculated chickens. Res. Vet. Sci., 30, 1981: 243-245.

CRITTENDEN, L. B.: Recent advances in the genetics of disease resistance. Avian Pathology, 12, 1983: $1-8$.

DILUZIO, N. R - WILLIAMS, D. - MCNAMEE, R B. - EDWARDS, B. F. - KITAHAMA, A: Comparative tumor-inhibitory and antibacterial activity of soluble and particulate glucan. Int. J. Canc., 24, 1979: 773-779.

DILUZIO, N. R - WILLIAMS, D. L.: The role of glucan in the prevention and modification 
of microparasitic diseases. In: Chemical regulation of immunity in veterinary medicine, 1983: 443-456. Edited by M. Kende, J. Gainer and M. Chirigos. Alan R. Liss, Inc. New York. JENDREYKO, M.: Correlation between rearing performance and results obtained from virological, histological, patho-morphological and clinical investigations in context of fresh-egs production over eight years (in German). Arch. exper. Vet. med. (Leipzig), 41, 1987: 869-873.

MULCAPHY, G. - QUINN, P. J.: A review of immunomodulators and their application in veterinary medicine. J. Vet. Pharmacol. Ther., 9, 1986: 119-139.

PETROVSKÝ, E - KALOVÁ J. - BENDA, V.: Antibody response in domestic fowl as affected by different immunisation methods. Acta Vet. Brno, 56, 1987: 449-453.

RIGGI, S. J. - DILUZIO, N. R.: Identification of a RE stimulating agent in zymosan. Amer. J. Physiol., 200, 1961: 297-300.

RfHOVA, B. - DROBNIK, J. - RfHA, I.: Immunostimulatory effect of cis-diamine dichloroplątinum (II). Immunol. Letters, 8, 1984: 57-60.

VAN DER ZIJPP, A. J.: Breeding for immune responsiveness and disease resistance. W. P. S. A. Journal, 39, 1983: 118-131.

WARREN, H. S. - VOGEL, F. R. - CHEDIC, L. A. Current status of immunological adjuvants. Inter. Rev. Immunol., 4, 1986: 369-388. 